\title{
Cleorodes Warren, 1894 does not belong in the tribe Boarmiini (Lepidoptera: Geometridae)
}

\author{
JAAN VIIDALEPP ${ }^{1}$, TOOMAS TAMMARU ${ }^{2 *}$, NIINA SNÄLL ${ }^{3}$, KAI RUOHOMÄKI $^{4}$ and NIKLAS WAHLBERG ${ }^{3,5}$ \\ ${ }^{1}$ Institute of Agricultural and Environmental Sciences, Estonian University of Life Sciences, Kreutzwaldi 64, EE-51014 Tartu, \\ Estonia \\ ${ }^{2}$ Institute of Zoology and Hydrobiology, University of Tartu, Vanemuise 46, EE-51014 Tartu, Estonia \\ ${ }^{3}$ Laboratory of Genetics, Department of Biology, University of Turku, FI-20014 Turku, Finland \\ ${ }^{4}$ Section of Ecology, Department of Biology, University of Turku, FI-20014 Turku, Finland \\ ${ }^{5}$ Department of Zoology, Stockholm University, S-106 91 Stockholm, Sweden
}

Key words. Taxonomy, morphology, molecular phylogeny, direct optimisation, Geometridae, Ennominae, Gnophini, Boarmiini, Bistonini, Cleorodes lichenaria

\begin{abstract}
The geometrid genus Cleorodes is shown to belong in the tribe Gnophini (sensu lato) and not in Boarmiini as previously assumed. The conclusion is based on an analysis of morphological characters of a number of genera in these tribes. Moreover, the result is unambiguously supported by a phylogenetic analysis of DNA sequence variation in three nuclear gene regions (segments D1 and D2 of 28S rRNA, and elongation factor $1 \alpha$ ) and a mitochondrial gene, cytochrome oxidase-1. The phylogenetic hypothesis is based on a combined sequence data set, which was analysed using direct optimisation.
\end{abstract}

\section{INTRODUCTION}

The largest subfamily of Geometridae, the Ennominae, with over 9700 described species (about 45\% of all Geometridae: Minet \& Scoble, 1999), is well defined by a morphological character, the weakening or absence of the vein M2 in the hind wings. On the other hand, there is no consensus about the taxonomic affinities of the numerous currently recognized tribes within the subfamily. Nevertheless, with few exceptions, these can be divided into two major branches on the basis of a pupal character, the structure of the cremaster (Forbes, 1948; Holloway, 1994). In particular (Fig. 1A, B), the cremaster may either (1) end in two separate stout $\left(\mathrm{D}_{2}\right)$ setae, associated with three pairs of thin, hooked side setae $\left(\mathrm{D}_{1} ; \mathrm{Sd}_{1} ; \mathrm{L}_{1}\right)-$ defining the informal "ennomine group" of tribes -, or (2) lack the side setae (Fig. 1C, D) and end in a cone- or stick-shaped, apically bifid projection, a condition characteristic of the "boarmiine group" of tribes (compare also text figures 119 and 122 in Hausmann, 2001). It is proposed that the former, i.e. the combination of 2 stout +6 side setae is ancestral for Ennominae, and the loss of the side setae in e.g. Macariini, Bistonini and Boarmiini represents a derived condition (Holloway, 1994).

Within the group with a bifid cremaster, a high number (131 species listed by Prout 1912-1916) of geometrid moths were initially grouped within the genus Boarmia Treitschke, 1825. Later, Wehrli (1939-53) subdivided the large Boarmia into numerous subgenera. More recently, the subgenera were raised to the rank of genera (Herbulot, 1961-1962; Leraut, 1997), and considered to collectively form the tribe Boarmiini within the subfamily
Ennominae. These moths are relatively uniform in appearance, with the wing pattern resembling tree bark, and have traditionally been viewed as an uncontroversial natural unit. Some differently looking genera have been added to the tribe (e.g. Arichanna, by Herbulot, 1962), but the systematic position of any of the "classical Boarmias" has never been questioned, neither has the tribe as a whole been subjected to a systematic taxonomic revision.

As a particular example, Cleorodes Warren, 1894 is treated as a separate genus within the Boarmiini group by all recent authors, e.g. Müller (1996), Viidalepp (1996), Leraut (1997) and Scoble (1999). The genus, with its single, lichenivorous (e.g. Pöykkö, 2006) European species C. lichenaria Hufnagel, 1767, was considered to be monotypic for a long time. Quite recently, however, another species, C. incerta Rungs, 1975 was described from Morocco. To our knowledge, no one has ever raised doubts concerning the taxonomic affinities of the genus. Consistently, Patočka \& Turčáni (2005), in their monograph on the pupal morphology of European Lepidoptera, group Cleorodes in the Boarmiini. Notably, however, in this key, this genus is reached between geometrids representing the ennomine group of tribes; i.e. as compared to the rest of the traditional Boarmias, it appears on the other side of the major morphological watershed subdividing the subfamily. Patočka \& Turčáni (2005) did not, however, comment on this situation.

In this paper, we show that $C$. lichenaria, in addition to an ennomine cremaster in the pupal stage (Fig. 1A), possesses also a number of other morphological traits that clearly distinguish it from typical representatives of Boar-

\footnotetext{
* Corresponding author; e-mail: toomas.tammaru@ut.ee
} 


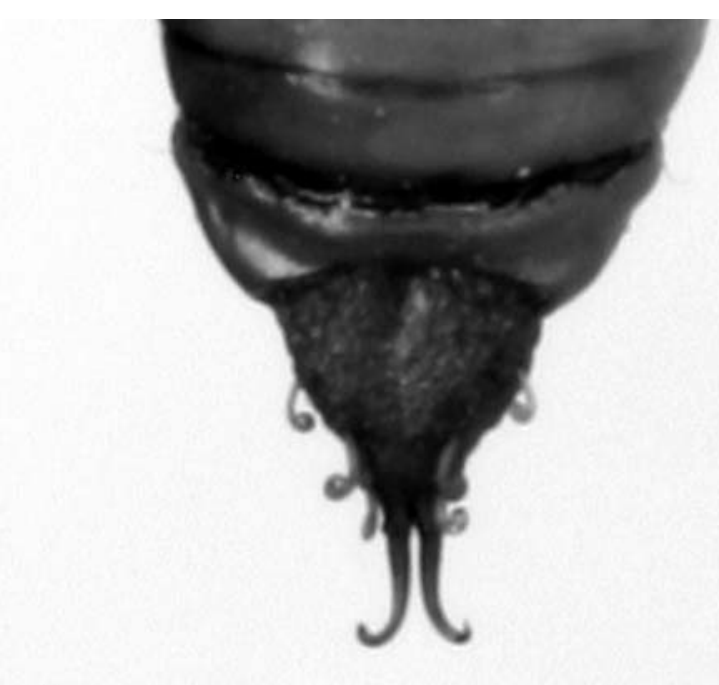

A
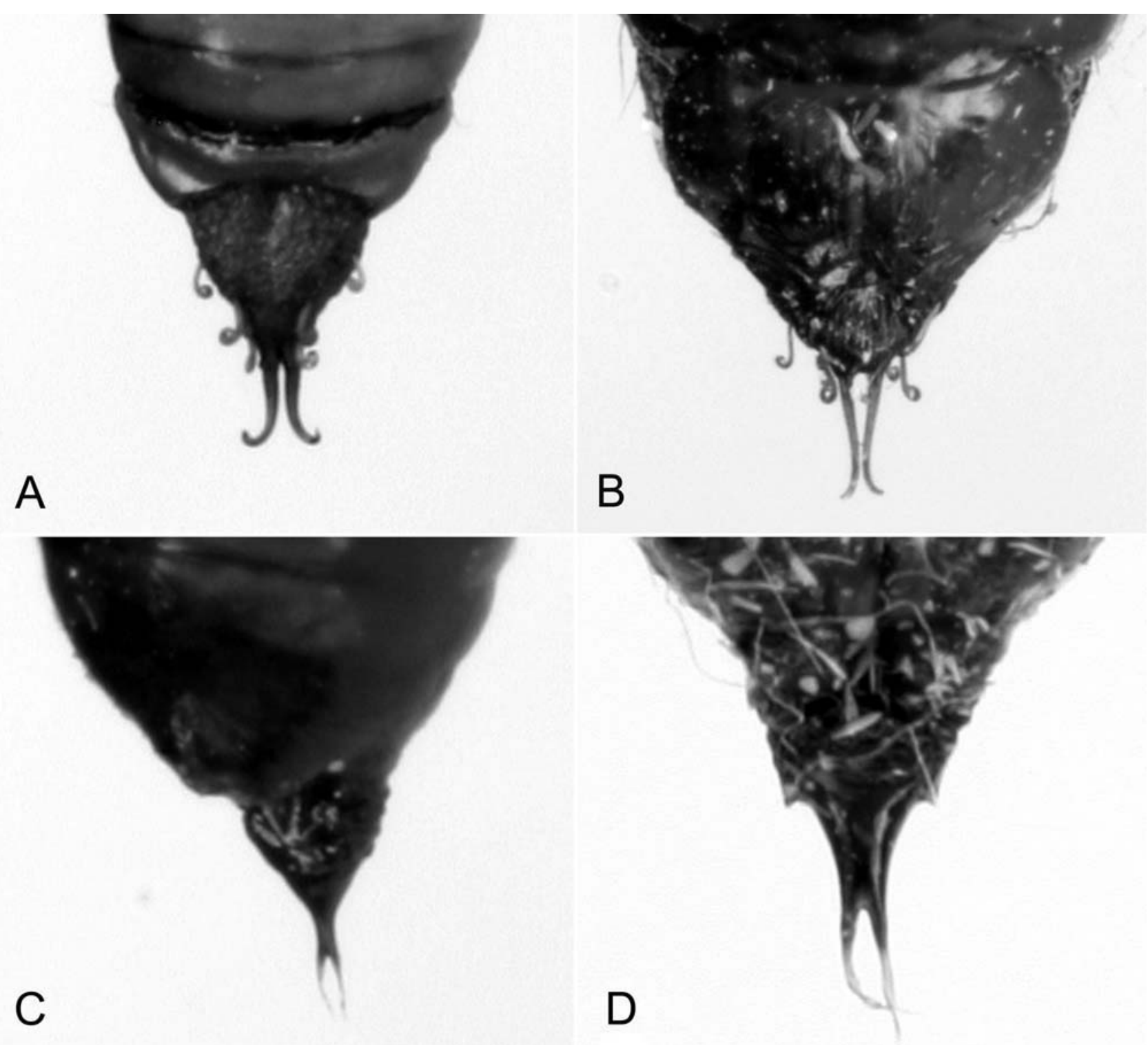

Fig. 1. Pupal cremasters of A - Cleorodes lichenaria (Gnophini), B - Crocallis elinguaria (Ennomini), C - Alcis repandata (Boarmiini), and D - Phigalia pilosaria (Bistonini).

miini, and indicate affinities with the tribe Gnophini in the broad sense. This is supported by a rigorous phylogenetic analysis of DNA sequences. It is concluded that Cleorodes is a gnophine, not a boarmiine genus as traditionally assumed.

\section{MATERIAL AND METHODS}

\section{Morphological study}

Along with $C$. lichenaria, 64 Palaearctic species representing 37 genera of the geometrid subfamily Ennominae (Appendix) were examined with the aim to find and/or confirm distinctive characters of the tribes Boarmiini, and the closely related Bistonini, on the one hand; and Gnophini, on the other. The concept of Gnophini used in this study is a broad one (sensu Herbulot, 1961-62, including e.g. Aspitates, Dyscia and Siona). The still unsolved question of delimitation of the tribes included in the ever more broad concept of the Boarmiini by Holloway (i.e. Gnophini, Boarmiini and Bistonini) requires a major revision of respective genera and is beyond the scope of the present paper.
For the morphological study, moths from the collection of the Estonian University of Life Sciences, Tartu, Estonia, were used. Both female and male genitalia, as well as pupal exuviae, were examined when suitable material was available. Examination of genitalia followed procedures described by Hardwick (1950). Pupae were photographed with a Canon 350D. The digital images were enhanced using Adobe Photoshop.

To formalize the results, a morphology-based cladistic hypotheses of respective genera (Appendix) was derived using the application Hennig86. The data set consisted of 66 characters for 22 ingroup taxa and Larentia clavaria Treitschke, 1825 was used as an outgroup species for tree rooting. All characters were scored with the plesiomorphic state as zero for convenience and considered nonadditive. These analyses constitute, however, a part of a broader morphological study of Ennominae, which will be presented elsewhere (Viidalepp, in prep.). Therefore, the results of the parsimony analysis of morphological data will be discussed here only in the context of the present communication. 
TABLE 1. Information on the geometrids used in the molecular analyses. Collection site (EST - Estonia, FIN - Finland, SWE Sweden) and year, collector's name, and GenBank accession numbers of sequences are indicated.

\begin{tabular}{|c|c|c|c|c|c|c|}
\hline Species & $\begin{array}{l}\text { Collection site } \\
\text { and year }\end{array}$ & Collector & 28S D1 & 28S D2 & $E F-1 \alpha$ & $\mathrm{COI}$ \\
\hline \multicolumn{7}{|l|}{ INGROUP } \\
\hline \multicolumn{7}{|l|}{ ENNOMINAE } \\
\hline \multicolumn{7}{|l|}{ Bistonini } \\
\hline $\begin{array}{l}\text { Biston betularia (Linnaeus, } \\
1758 \text { ) }\end{array}$ & EST, Karilatsi, 2004 & T. Tammaru & EF206658 & EF206666 & EF206673 & EF206681 \\
\hline $\begin{array}{l}\text { Erannis defoliaria (Clerck, } \\
1759)\end{array}$ & FIN, Hanko, 2003 & $\begin{array}{l}\text { H.Takanen, } \\
\text { A.Teräs, } \\
\text { K.Ruohomäki }\end{array}$ & EF206665 & - & EF206680 & EF206688 \\
\hline \multicolumn{7}{|l|}{ Boarmiini } \\
\hline $\begin{array}{l}\text { Hypomecis punctinalis } \\
\text { (Scopoli, 1763) }\end{array}$ & EST, Avinurme, 2004 & T. Tammaru & EF206660 & EF206668 & EF206675 & EF206683 \\
\hline $\begin{array}{l}\text { Peribatodes secundaria } \\
\text { (Denis \& Schiffermüller, 1775) }\end{array}$ & EST, Ruhnu, 2005 & T. Tammaru & EF206661 & EF206669 & EF206676 & EF206684 \\
\hline \multicolumn{7}{|l|}{ Ennomini } \\
\hline $\begin{array}{l}\text { Ennomos fuscantaria } \\
\text { (Haworth, 1809) }\end{array}$ & FIN, Turku, 2000 & K. Ruohomäki & EF206659 & EF206667 & EF206674 & EF206682 \\
\hline \multicolumn{7}{|l|}{ Gnophini } \\
\hline Siona lineata (Scopoli, 1763) & EST, Karilatsi, 2005 & T. Tammaru & EF206663 & EF206671 & EF206678 & EF206686 \\
\hline $\begin{array}{l}\text { Kemtrognophos ambiguata } \\
\text { (Duponchel, 1830) }\end{array}$ & EST, Taheva, 2004 & T. Tammaru & EF206664 & EF206672 & EF206679 & EF206687 \\
\hline $\begin{array}{l}\text { Cleorodes lichenaria } \\
\text { (Hufnagel, 1767) }\end{array}$ & EST, Tõstamaa, 2005 & T. Tammaru & EF206662 & EF206670 & EF206677 & EF206685 \\
\hline
\end{tabular}

ARCHIEARINAE

Archiearis parthenias

(Linnaeus, 1761)

SWE, Stockholm 2003 N. Wahlberg AF178897* AF178897* DQ018899** DQ018928**

OUTGROUP

LARENTIINAE

Epirrita autumnata

(Borkhausen, 1794)

FIN, Masku, $2000 \quad$ K.Ruohomäki AY948443*** AY948463*** AY948465*** EF206689

-, not available; *, Abraham et al., 2001; **, Wahlberg et al., 2005; ***, Snäll et al., 2007.

\section{Molecular analysis}

In addition to $C$. lichenaria, two representatives of Boarmiini, Bistonini and Gnophini (sensu lato, see above) were included in the phylogenetic analysis of DNA sequences. A species of Ennomos was added as a typical representative of the informal group of the "ennomine tribes". To root the tree, two species from the subfamilies Archiearinae and Larentiinae were also considered, the latter being defined as an outgroup. The taxa used, along with where the specimens were collected, and GenBank numbers of the sequences, are listed in Table 1. To exclude the possibility of a technical mistake, another specimen of $C$. lichenaria, from the same location, was examined and found to have identical sequences in particular gene regions.

Using a DNeasy ${ }^{\mathrm{TM}}$ Tissue Kit (Qiagen, Hilden, Germany), genomic DNA was extracted from freshly captured moths which were dried, frozen, or preserved in alcohol. Only parts of the specimens were used for DNA extraction, which allowed the voucher specimens to be preserved. For the phylogenetic analysis, the portions of two nuclear genes, D1 and D2 segments of the 28S rRNA gene and the elongation factor $1 \alpha(E F-1 \alpha)$ gene, and a portion of a mitochondrial gene, cytochrome oxidase- 1 (COl) gene, were sequenced. PCR reactions were carried out with 5-100 ng of DNA template, $0.1 \mu \mathrm{M}$ of each primer, 200 $\mu \mathrm{M}$ of each dNTP, $1 \mathrm{U}$ of DyNAzyme ${ }^{\mathrm{TM}}$ II DNA polymerase
(Finnzymes Oy) in $1 \times$ DyNAzyme $^{\mathrm{TM}}$ buffer supplemented with $1.5 \mathrm{mM} \mathrm{MgCl}_{2}$ in a PTC-100 Peltier Thermal Cycler (MJ Research Inc.) or in a Eppendorf Mastercycler ${ }^{\circledR}$ gradient (Perkin-Elmer Corp.).

For the amplification of the segments of the 28S rRNA gene, the 28S D1 primers (Larsen, 1992) and the 28S D2 primers (Belshaw \& Quicke, 1997) were used. The EF-1 $\alpha$ fragment was amplified either as whole with the primers EF44 and EFrcM4 (Monteiro \& Pierce, 2001) or in two overlapping pieces. The 5' half of the $E F-1 \alpha$ fragment was amplified using the primer pair of Cho2 (5'-CTACGTCACCATCATCGA-3') and Verdi4 (5'CACCAGTCTCCACACGGCC-3'). The 3' half of the $E F-1 \alpha$ fragment was amplified using the forward primer EF51.9 (Monteiro \& Pierce, 2001) with either one of the reverse primers, Niina (5'-CCACAGACAAGGCCCTGCG-3') or Niina2 (5'CCTGGAAGGACTCCACRCACAG-3'). The CO1 fragment was amplified using the primers LCO2198 and HCO1490 (Folmer et al., 1994). PCR conditions were as follows: an initial denaturation at $95^{\circ} \mathrm{C}$ for $5 \mathrm{~min}, 35$ cycles of $30 \mathrm{~s}$ at $95^{\circ} \mathrm{C}, 30 \mathrm{~s}-$ $1.5 \mathrm{~min}$ at $49-57.5^{\circ} \mathrm{C}$ (depending on the gene fragment and the primer pair), $1 \mathrm{~min}$ at $72^{\circ} \mathrm{C}$ and a final extension at $72^{\circ} \mathrm{C}$ for 10 min. The PCR products were purified using the GFX ${ }^{\mathrm{TM}} \mathrm{PCR}$ DNA and Gel Band Purification Kit (Amersham Pharmacia Biotech Inc., Piscataway, N.J.). The sequencing was conducted using the automatic ABI PRISM ${ }^{\mathrm{TM}} 377$ or $3130 \mathrm{xl}$ DNA 
TABLE 2. Discriminative characters for the genus Cleorodes, and putative related groups. The table is based on the examination of a sample of Palearctic genera (see Appendix).

\begin{tabular}{|c|c|c|c|}
\hline & Bistonini + Boarmiini & Cleorodes & Gnophini \\
\hline 1 & $\begin{array}{l}\text { Pupa: cremaster setae } \mathrm{D}_{1}, \mathrm{SD}_{1} \text { and } \mathrm{L}_{1} \text { reduced, } \\
\mathrm{D}_{2} \text { fused into a stem }\end{array}$ & \multicolumn{2}{|c|}{ Cremaster with setae $D_{1}, S D_{1}, L_{1}$ and $D_{2}$ present, setae $D_{2}$ separated } \\
\hline 2 & $\begin{array}{l}\text { Male abdominal sternite A3 with a transverse comb } \\
\text { of setae (Boarmiini), or hair lock (Bistonini) }\end{array}$ & \multicolumn{2}{|c|}{ Male abdominal sternite A3 without a comb of stiff setae } \\
\hline 3 & $\begin{array}{l}\text { Male antennae, if pectinated, then with apical } \\
\text { segments filiform }\end{array}$ & Pectinated to apical segments & Often pectinated to the apical segments \\
\hline 4 & $\begin{array}{l}\text { Male forewing with fovea present (Boarmiini), } \\
\text { or absent (Bistonini) }\end{array}$ & Fovea lacking in males & $\begin{array}{c}\text { Fovea usually lacking in male } \\
\text { forewings }\end{array}$ \\
\hline 5 & $\begin{array}{l}\text { Gnathos as strong as uncus and provided with } \\
\text { cochlear (its medial projection) }\end{array}$ & Gnathos reduced & $\begin{array}{l}\text { Uncus or gnathos often reduced, or } \\
\text { gnathos longer than uncus, jaw-shaped }\end{array}$ \\
\hline
\end{tabular}

Sequencer with the ABI PRISM ${ }^{\circledR}$ BigDye $^{\mathrm{TM}}$ Terminator Kit (Applied Biosystems, Foster City, CA). The gene fragments were sequenced in both directions (28S D1 and D2) or in one direction $(E F-1 \alpha$ and $C O 1)$ with their PCR primers. The sequences were edited with the Sequencher ${ }^{\mathrm{TM}}$ v.3.1.1 (Gene Codes Corp., Ann Arbor, MI, USA).

\section{Phylogenetic analysis of molecular data}

The sequencing of the three nuclear and one mitochondrial gene fragments produced an average of $2326 \mathrm{bp}$ sequence data for phylogenetic analysis. The obtained sequences for all gene fragments varied in length due to the PCR amplification and sequencing techniques (e.g. primer combinations used, ambiguities in sequence ends), whereas only 28S D1 and D2 fragments were of variable length due to indels. The average lengths of the gene partitions were as follows: 285 bp for $28 \mathrm{~S} \mathrm{D1}, 441 \mathrm{bp}$ for 28S D2, $959 \mathrm{bp}$ for $E F-1 \alpha$, and $641 \mathrm{bp}$ for $C O 1$. The incongruence length difference test (Farris et al., 1994), which was used to test for the combinability of the different gene partitions, showed no significant incongruity between data sets $(P>0.9)$. The PCR amplification of the 28S D2 sequence of $E$. defoliaria was unsuccessful, and thus the molecular data used lack this sequence.

The combined sequence data sets were analysed via direct optimisation using the program POY v.3.0.11 (Wheeler et al., 2003). The fragments of $E F-1 \alpha$ and $C O 1$ were pre-aligned and analysed with the 1:1:1 (transiton : transversion : gap) parameter set. 28S D1 sequences, which showed a 2 bp length variation, were also analysed with the 1:1:1 parameter set. The highly length variable 28S D2 sequences were cut into three fragments flanked by conservative regions and were analysed with ten different parameter values: $1: 1: 1,1: 1: 2,1: 1: 4,1: 1: 6,1: 1: 8,1: 2: 1$, $1: 2: 2,1: 2: 4,1: 2: 6$, and 1:2:8. Ten implied alignments, one from each of these 28S D2 POY analyses, were combined using the elision procedure, which is a method for accommodating multiple alignments with alignment-ambiguous sites (Wheeler et al., 1995). All characters of the elised D2 data set were downweighted by a factor 10 . This gives the same weight to the characters in the D2 data set as to characters in other, non-elised data sets. The POY command line for all the runs was as follows: - fitchtrees - noleading - norandomizeoutgroup impliedalignment - sprmaxtrees 1 - tbrmaxtrees 1 - maxtrees 5 - holdmaxtrees 50 - slop 5 - checkslop 10 - buildspr - buildmaxtrees 2 - random 5 - stopat 25 - multirandom - treefuse fuselimit 10 - fusemingroup 5 - fusemaxtrees 100 - numdriftchanges 30 - driftspr - numdriftspr 10 - drifttbr - numdrifttbr 10 - slop 10 - checkslop 10.

To find the most parsimonious tree(s), the differentially weighted combined datasets were analysed with WinClada v.10.00.08 (Nixon, 2002) running NONA v.2.0 (Goloboff,
1999). Support for the internal nodes was calculated using bootstrap analysis (1000 pseudoreplications, five search replications, two starting trees per replication).

\section{RESULTS AND DISCUSSION}

Our morphological analysis of Palaearctic taxa showed that the tribes Boarmiini and Bistonini (sensu Herbulot, 1961-1962) share several well-defined characters that distinguish them from the representatives of the informal "ennomine group" of tribes (Table 2), and each have some of their own synapomorphies. In addition to the distinctive, and presumably derived, pupal character - the loss of side setae and fusion of $\mathrm{D}_{2}$ setae on cremaster, the modification of male abdominal sternite A3 deserves attention as a taxonomically promising synapomorphy. The question about the universal validity of these diagnostic traits cannot, however, be answered prior to a comprehensive phylogenetic study of the world fauna.

Holloway (1994: p. 167) combined all the genera with the derived cremaster condition, shared possession of a fovea and of a transverse comb on the sternite A3 in males, in the Boarmiini sensu lato. However, earlier Pierce (1914) distinguished between the Boarmiini (characterized by spinose valva) and Bistonini (valva smooth), and this distinction was adopted in by the majority of subsequent taxonomic works (Herbulot, 1961-1962; Leraut, 1997). The distinction is well supported morphologically (Viidalepp, 1989). In particular, in Bistonini, pupae are characterized by angulate lateral projections on a stout cremaster, and by the absence of labium and fore femur (Patočka, 1986). Bistonine moths, so far studied by the authors, (1) lack a fovea at the base of the male forewing, and (2) the setal comb ventrally on sternite A3 is lacking or replaced by a tuft of white hairscales. Bistonine taxa also have (3) uncus often ventrally bi-pointed and (4) valva in male genitalia usually simple, parallel-sided with strong costal region and (5) lack a harpe. Female genitalia are often characterized by (6) very long apophyses with oral tips flattened. Of the genera examined in this study, the following six share the listed "bistonine" characters, or most of them: Apocheima, Biston, Erannis, Larerannis, Lycia, and Phigalia. However, Apocheima and Erannis are exceptional in the presence of a thorny harpe on centre of valva in males. 


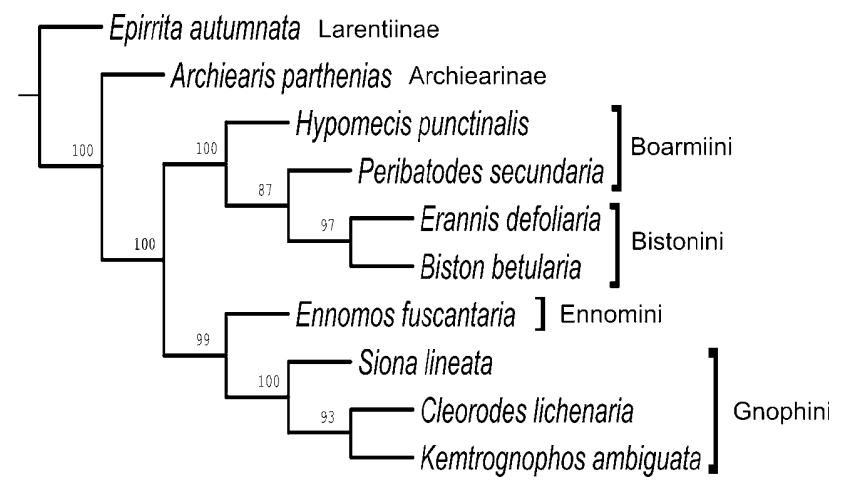

Fig. 2. The maximum parsimony tree of eight geometrid species from the subfamily Ennominae. The tree is based on the combined sequence data of three nuclear and one mitochondrial gene fragment, analysed via direct optimisation in the program POY. The tree was rooted to Larentiinae and Archiearinae species. "Gnophini" is used in its broad sense (Herbulot, 1961-62). Numbers above the branches indicate bootstrap support values.

The genera of Boarmiini s. str. examined have a stickshaped, apically bifid projection on the cremaster which lacks lateral angulation. These moths typically also possess (1) well delimited harpe and cucullus on male valva, (2) a setal comb on sternite A3, and (3) a deep fovea on male forewing (with rare exceptions). Uncus is triangular with a short, finger-like distal projection, the gnathos is usually well sclerotised and provided with a strong, flat medial cochlear. In only one case, the ovipositor is telescopic with the apophyses longer than usual (Ectropis). The following seven genera share the "boarmiine sensu stricto" characters: Aethalura, Alcis, Cleora, Deileptenia, Ectropis, Paradarisa, Peribatodes.

Holloway (1994) did not investigate the Gnophini in detail but included the group within his broadly defined Boarmiini. Morphological evidence, however, appears not to conform with this suggestion. Above all else, gnophine moths (with the exception of Gnophos itself, which differs in having a bicornute cremaster) possess the diagnostic pupal character, i.e. the distinctive combination of setae on cremaster (Patočka \& Turčáni, 2005; Fig. 1A, $\mathrm{B})$, which indicates that they belong to the "ennomine" group of tribes. Gnophini (sensu Herbulot, 1962) are characterized by a combination of the following characters: (1) the uncus short and birdhead-shaped; (2) the absence of a fovea on forewings; and (3) the absence of a comb of setae on abdominal sternite A3 in males; (4) a costal projection on valva usually present, bearing a spine or group of spines; (5) the juxta is often H-shaped with short basal and longer distal appendages. Of the genera studied: Acrognophos, Arbognophos, Aspitates, Bizia, Chariaspilates, Charissa, Chelegnophos, Cnestrognophos, Costignophos, Ctenognophos, Dyscia, Euchrognophos, Napuca, Nychiodes, Odontognophos, Dicrognophos, Dysgnophos, Elophos, Kemtrognophos, Pterygnophos, Rhipignophos, Rhopalognophos, Zystrognophos and, notably, Cleorodes, share the gnophine characters listed above. There is no doubt that $C$. lichenaria exhibits the "gnophine" spectrum of morphological char- acters (Table 2). Besides the distinctive cremaster condition (Fig. 1A), the short, convex, bird-head-shaped uncus provides perhaps the most convincing evidence. Cleorodes appears thus not to belong to the boarmiine branch of the subfamily Ennominae.

Consistently, the respective morphological parsimony analysis yielded a robust, fully resolved most parsimonious tree (to be presented elsewhere: Viidalepp, in prep.). The gnophine genera - including Cleorodes were supported by five strict synapomorphies (listed in the previous paragraph), and were placed basal to the boarmiine and bistonine lineages. Both of these were supported by strict synapomorphies of their own (for discussion of bistonine and boarmiine characters, see also Viidalepp, 1989).

The results of the phylogenetic analysis of the molecular data unambiguously support the conclusions of the morphological study. In particular, the direct optimisation procedure produced a tree with two well-supported clades within the Ennominae (Fig. 2), which correspond to the major morphology-based subdivision of the subfamily into two groups. One of the clades was formed by representatives of the tribes Boarmiini s. str. (H. punctinalis and P. secundaria) and Bistonini (B. betularia and $E$. defoliaria). The results are consistent with the morphology-based idea that the Bistonini are monophyletic (Table 2) but hint at the possibility that the Boarmiini s. str. may be paraphyletic. If this is the case, one may prefer a broader concept of the Boarmiini which subsumes the Bistonini. Obviously, however, a much wider taxon sampling is required to resolve this question.

On the other hand, the two members of the Gnophini s. lat. (S. lineata and K. ambiguata) clustered together and formed a monophyletic group, which also included $C$. lichenaria. The Gnophini grouped together with Ennomos, confirming the morphology-based (Patočka \& Turčáni, 2005) view that the genera of Gnophini, sensu Herbulot (1961-1962), belong to the ennomine branch of the subfamily (cf. Holloway, 1994).

In summary, both the morphological and molecular evidence suggest that the position of Cleorodes in the Ennominae should be reconsidered. The genus should be removed from the tribe Boarmiini, and preliminarily placed in the Gnophini. Establishing the relationships of Cleorodes within the latter group will, however, require a major revision of respective genera. Such a revision is urgently needed not only because of the disputed status of Aspitatini (Holloway, 1994) but also because the nominate genus of the tribe, Gnophos, appears not to share all of the putative morphological synapomorphies with the rest of "Gnophini".

ACKNOWLEDGEMENTS. H. Pöykkö kindly provided exuviae of $C$. lichenaria, R. Viidalepp prepared the microphotographs. The study was supported by the grant 111195 from the Academy of Finland, and grants 5750 and 5746 from the Estonian Science Foundation. NS was also supported by grants from the Finnish Cultural Foundation and the Finnish Konkordia Fund. 


\section{REFERENCES}

Abraham D., Ryrholm N., Wittzell H., Holloway J.D., Scoble M.J. \& LÖFSTEDT C. 2001: Molecular phylogeny of the subfamilies in Geometridae (Geometroidea: Lepidoptera). Mol. Phylogen. Evol. 20: 65-77.

Belshaw R. \& Quicke D.L.J. 1997: A molecular phylogeny of the Aphidiinae (Hymenoptera: Braconidae). Mol. Phylogen. Evol. 7: 281-293.

Farris J.S., KÄllersjö M., Kluge A.G. \& Bult C. 1994: Testing significance of incongruence. Cladistics 10: 315-319.

Folmer O., Black M.B., Hoch W., Lutz R.A. \& VRiJehock R.C. 1994: DNA primers for amplification of mitochondrial cytochrome c oxidase subunit I from diverse metazoan invertebrates. Mol. Mar. Biol. Biotechnol. 3: 294-299.

ForBES J.T.W. 1948: Lepidoptera of New York and neighboring states, 2. Memoirs Cornwell University Agriculture Experimental Station. No. 274. 263 pp.

GolobofF P.A. 1999: NONA. Published by the author, Tucumán, Argentina.

HaRdwick D.F. 1950: Preparation of slide mounts of Lepidopterous genitalia. Can. Entomol. 82: 231-235.

Hausmann A. 2001: The Geometrid Moths of Europe. Vol. 1. Apollo Books, Stenstrup, 282 pp.

Herbulot C. 1961-1962: Mise à jour de la liste des Geometridae de France. Alexanor (Paris) 2: 117-124, 147-154; 3: $17-24,85-93$.

Holloway J.D. 1994: The moths of Borneo, Part 11. Geometridae Ennominae. Malayan Nat. J. 47[1993]: 1-309.

Larsen N. 1992: Higher order interactions in 23S rRNA. Proc. Natl. Acad. Sci. U. S. A. 89: 5044-5048.

Leraut P. 1997: Liste systématique et synonymique des Lépidoptères de France, Belgique et Corse. Alexanor (Paris) (Suppl.) 566 pp.

Minet J. \& Scoble M.J. 1999: The Drepanoid / Geometroid Assemblage. In Kristensen N.P. (ed.): Lepidoptera, Moths and Butterflies. Vol. 1: Evolution, Systematics, and Biogeography. Part 35. Handbook of Zoology IV. De Gruyter, Berlin and New York, pp. 301-320.

Monteiro A. \& Pierce N.E. 2001: Phylogeny of Bicyclus (Lepidoptera: Nymphalidae) inferred from COI, COII, and EF-1 $\alpha$ gene sequences. Mol. Phylogen. Evol. 18: 264-281.

Müller B. 1996: Geometridae. In Karsholt O. \& Razowski J. (eds): The Lepidoptera of Europe. A distributional Checklist. Apollo Books, Stenstrup, pp. 218-249, 329-332.

Nixon K.C. 2002: Winclada. Published by the author, Ithaca, New York.

PAtočKa J. 1986: Zur Kenntnis der Puppen der Tribus Boarmiini (Lepidoptera, Geometridae) von Mitteleuropa. Acta Entomol. Bohemoslov. 83: 301-315.

PAtočKa J. \& TurČÁNi M. 2005: Lepidoptera Pupae. Central European Species. Apollo Books, Stenstrup, $542+321$ pp.

PIERCE F.N. 1914: The Genitalia of The Group Geometridae of the Lepidoptera of the British Islands. Liverpool, 86 pp., 48 pls.

РӦYкKÖ H. 2006: Females and larvae of a geometrid moth, Cleorodes lichenaria, prefer a lichen host that assures shortest larval period. Environ. Entomol. 35: 1669-1676.

Prout L.B. 1912-1916: Spannerartige Nachtfalter. In Seitz A. (ed.): Die Gross-Schmetterlinge der Erde, 4. A. Kernen, Stuttgart, 480 pp., 25 pls.

Scoble M.J. 1999: Geometrid Moths of the World: A Catalogue (Lepidoptera, Geometridae). CSIRO Publishing \& Apollo Books, Stenstrup, $1016+129$ pp.

Snäll N., Tammaru T., Wahlberg N., Vitdalepp J., Ruohomäki K., Savontaus M.-L. \& Huoponen K. 2007: Phylogenetic relationships of the tribe Operophterini (Lepidoptera, Geometridae): a case study of the evolution of female flightlessness. Biol J. Linn. Soc. (in press).

VIIDALEPP J. 1989: A new genus and a new tribus of Geometrid moths (Lepidoptera, Geometridae: Desertobini, trib.n.). Trudy Zool. Inst. Leningr. 200: 94-109 [in Russian].

VIIDALEPP J. 1996: Checklist of the Geometridae (Lepidoptera) of the Former U.S.S.R. Apollo Books, Stenstrup, 111 pp.

Wahlberg N., Braby M.F., Brower A.V.Z, de Jong R., Lee M.-M., Nylin S., Pierce N., Sperling F.A., Vila R., Warren A.D. \& ZaKhAROV E. 2005: Synergistic effects of combining morphological and molecular data in resolving the phylogeny of butterflies and skippers. Proc. R. Soc. Lond. (B) 272: $1577-1586$.

Wehrl E. 1939-1953: Ennominae. In Seitz A. (ed.) Die GrossSchmetterlinge der Erde, Suppl. 4. A. Kernen, Stuttgart, pp. 254-718.

Wheeler W.C., Gatesy J. \& DeSalle R. 1995: Elision: A method for accommodating multiple molecular sequence alignments with alignment-ambiguous sites. Mol. Phylogen. Evol. 4: 1-9.

Wheeler W.C., Gladstein D. \& De Laet J. 2003: POY, phylogeny reconstruction via optimization of DNA and other data, version 3.0.11 (May 6, 2003), 67 pp.

\section{APPENDIX}

List of geometrid genera (species) examined morphologically. The taxonomy and systematical arrangement follow Viidalepp (1996); however, we have followed Patočka and Turčáni (2005) in transferring aurantiaria and marginaria from Agriopis Hübner, 1825 to Larerannis Wehrli, 1935. Pupal characters were only available for some species, either from the literature (marked with $*$ ) or were directly examined on collection specimens $(* *)$.

Acrognophos Wiltshire, 1967 (iveni Erschov, 1874)

Arbognophos Viidalepp, 1979 (amoenaria Staudinger, 1897)

Bizia Walker, 1860 (grandinaria Motschulsky, 1860)

Aspitates Treitschke, 1825 (acuminaria Eversmann, 1851; stshurowskyi Erschow, 1874)

Chariaspilates Wehrli, 1953 (*formosaria Eversmann, 1837)

Charissa Curtis, 1826 (obscurata Denis \& Schiffermüller, 1775)

Chelegnophos Wehrli, 1951 (alaianus Viidalepp, 1988; fractifasciata Püngeler, 1901)

Cnestrognophos Wehrli, 1951 (quadrimaculata Chrétien, 1913; adjectaria Staudinger, 1897; subvariegata Staudinger, 1898)

Costignophos Wehrli, 1951 (*pullata Denis \& Schiffermüller, 1775)

Ctenognophos Prout, 1915 (eolaria Guenée, 1858, tetarte Wehrli, 1931, burmesteri Graeser, 1888)

Dicrognophos Wehrli, 1951 (sartata Treitschke, 1825)

Dyscia Hübner, 1825 (innocentaria Christoph, 1885; malatyana Wehrli, 1934 a.o.)

Dysgnophos Wehrli, 1951 (turfosaria Wehrli, 1922; sibiriata Guenée, 1858 a.o.)

Elophos Boisduval, 1840 (*dilucidaria Denis \& Schiffermüller, 1775; dognini Thierry-Meig, 1910; *operaria Hübner, 1813; *caelibaria Heydenreich, 1858; *vittaria Thunberg, 1788)

Euchlaena Hübner, 1823 (marginaria Minot, 1869; serrata Drury, 1763)

Euchrognophos Wehrli, 1951 (annubilata Christoph, 1855; effendii Viidalepp \& Piriev, 1993; mucidaria Hübner, 1799; corsica Oberthür, 1913; *variegata Duponchel, 1830)

Gnophos Treitschke, 1825 (*obfuscata Denis \& Schiffermüller, 1775; *furvata Denis \& Schiffermüller, 1775)

Kemtrognophos Wehrli, 1951 (onustaria Herrich-Schäffer, 1852; *ambiguata Duponchel, 1830; remmi Viidalepp, 1988) 
Napuca Walker, 1863 (taylorae Butler, 1893 a.o.)

Nychiodes Lederer, 1853 (antiquaria Staudinger, 1892)

Odontognophos Wehrli, 1951 (perspersata Treitschke, 1827; zacharia Staudinger, 1878)

Pterygnophos Wehrli, 1951 (ochrofasciata Staudinger, 1895; agnitaria Staudinger, 1897)

Rhipignophos Wehrli, 1951 (praestigiaria Püngeler, 1902; tadzhikistanica Viidalepp, 1988)

Rhopalognophos Wehrli, 1951 (*glaucinarius Hübner, 1799)

Zystrognophos Wehrli, 1945 (sericaria Alphéraky, 1883; nimbata Alphéraky, 1888)

Aethalura McDunnough, 1920 (**punctulata Denis \& Schiffermüller, 1775)

Alcis Curtis, 1826 (**repandata Linnaeus, 1758 a.o.)

Apocheima Hübner 1825 (*hispidaria Denis \& Schiffermüller, 1775)

Biston Leach, $1815(* *$ betularia Linnaeus, 1758; *strataria Hufnagel, 1767)
Cleora Curtis, 1825 (** cinctaria Denis \& Schiffermüller, 1775)

Cleorodes Warren, 1894 (**lichenaria Hufnagel, 1767)

Deileptenia Hübner, 1825 (**ribeata Clerck, 1759)

Ectropis Hübner, 1825 (**bistortata Goeze, 1781)

Erannis Hübner, 1825 (tiliaria Harris, 1841; **defoliaria Clerck, 1759)

Larerannis Wehrli, 1935 (*marginaria Borkhausen, 1794; **aurantiaria Denis \& Schiffermüller, 1775)

Lycia Hübner, 1825 (** hirtaria Clerck, 1759; lapponaria Boisduval, 1840)

Paradarisa Warren, 1894 (**consonaria Hübner, 1799)

Peribatodes Wehrli, 1943 (*secundaria Denis \& Schiffermüller, 1775)

Phigalia Duponchel, 1829 (**pilosaria Denis \& Schiffermüller, 1775).

Received September 26, 2006; revised and accepted December 21, 2006 